\title{
Exposure of tobacco farm working mothers to pesticides and the effects on the infants' auditory health
}

Jaqueline Portella Buaski ${ }^{(1)}$

Cristiana Magni ${ }^{(1)}$

Cristina Ide Fujinaga(1)

Leslie Palma Gorski(1)

Juliana De Conto(1)

Universidade Estadual do Centro-Oeste UNICENTRO, Paraná, Brasil.

Conflict of interests: Nonexistent

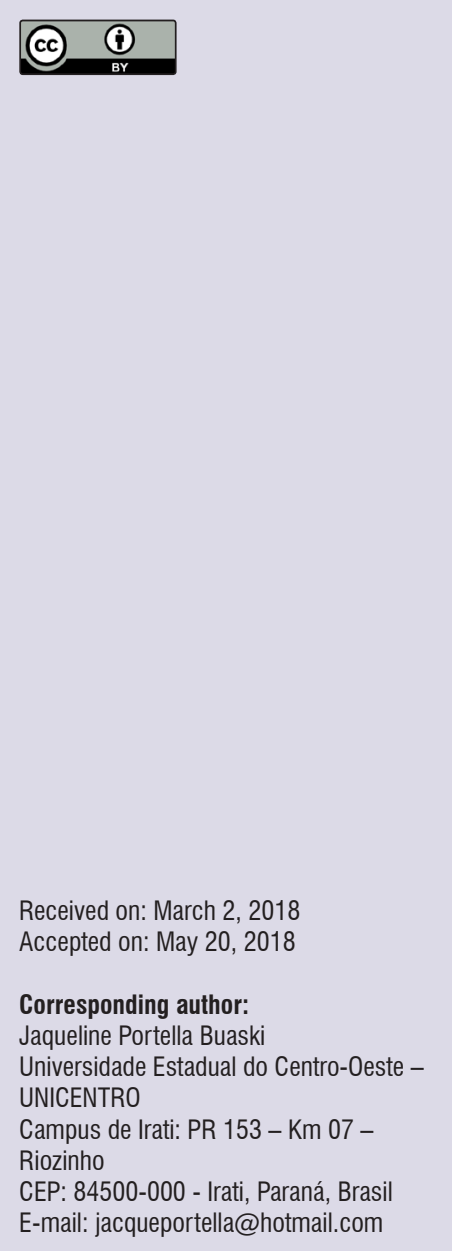

\section{ABSTRACT}

Objective: to check and compare female farm workers' and female tobacco farm workers' behavior related to the use of pesticides after the pregnancy diagnosis and their effect on the infants' hearing.

Methods: a cross-sectional analytical observational study developed with 59 female farming mothers. From these, 25 were tobacco farm workers (Group F) and 34 were farm workers for other crops (Group A - control). The results of the hearing screening of 59 infants, from both groups, were verified. The anamnesis to raise the risk factor indicators for hearing disabilities as well as the caption of Transient Evoked Otoacoustic Emissions (OAEs) was accomplished.

Results: tobacco farming is directly related to the use of pesticides $(p=0.0043)$; laundry of clothes worn to apply the pesticides is an indirect means of exposure/ contamination by pesticides and/or chemical substances $(p=0.018)$; the association between pass/fail results and Hearing Disabilities Risk Indicators (HDRI) of infants in both groups (tobacco farm workers and other workers) did not show significant statistical differences.

Conclusion: effects on the hearing health of infants of female tobacco farm workers and other farm workers exposed to pesticides were not found in this research. Further studies on this theme are suggested.

Keywords: Infant; Pregnancy; Hearing; Tobacco; Pesticides 


\section{INTRODUCTION}

Although farming has been explored by mankind for over ten thousand years, the intensive use of pesticides to control plagues and farm diseases has existed for a little more than half a century. It evolved after the world wars when chemical industry, poison manufacturer to be used as chemical weapons, found a new market in agriculture for its products ${ }^{1}$.

Brazil is the greatest pesticide consumer in the world, provoking direct impact on human health, comprising different population groups and workers from several fields and activities within large territories ${ }^{1}$. In tobacco farming, the study points out that the presence of poisoning symptoms is an evidenced reality and poses risk to tobacco farm workers' health, due to the intensive use of pesticides, and to the difficulty in complying with the use of protection equipment on the account of the singularities of tobacco farming ${ }^{2}$.

Pesticide use and handling in general farming are considered a prevalent male activity. However, that does not prevent women and other family members from the risk of indirect intoxication. In the Brazilian reality, it is usual that the responsible for applying the pesticide carries out that activity with his family, and without wearing the Equipment for Personal Protection (EPP). It should be pointed out that women usually do the laundry of those clothes worn for the pesticide application. In addition, the crops are closer and closer to the residences, where family members stay around, wearing improper clothes and shoes ${ }^{3}$.

Brazil leads food production after the United States, evidenced by the second crop estimate in 2017. Cereal, oil seed and vegetable production, in tons, exceeds the one in 2016, being rice, corn and soybeans, the three leading products in this group. Among the large farming regions, Mato Grosso State has the leadership in grain production, followed by Paraná State with around $18.7 \%{ }^{4}$. According to the Union of Tobacco Industries (SINDITABACO), Brazil is the first world tobacco exporter and, as a producer, it holds the second place. Southern region has $96 \%$ of the national production, and Paraná State holds $19 \%$ of that production 4 .

According to the State Secretary of Agriculture and Supply in Paraná State ${ }^{5}$, the region of Irati is the greatest tobacco producer, responsible for $26 \%$ of the total production in the state. Thus, tobacco is the leading crop in Irati, and its growth brings along the elevated use of chemicals and the absence of specific care for the tobacco farm workers ${ }^{6}$.
Between 1970 and 2000, there was a shift in tobacco production settings, when it moved mainly to developing countries, such as Brazil, which led to the use of women, black people and immigrants' cheap workforce ${ }^{7}$.

Rural work in tobacco fields, carried out by families, holds unique characteristics, as the production process involves the whole family, and in the case of an event which affects a family member, that may echo and threaten their subsistence. Thus, there is an increasing exposure to hazards and occupational disease ${ }^{8}$, mainly among the women ${ }^{9,10}$.

Farming work division by gender enables to conclude that women occupy a subordinate position, and their work looks like just 'help', even when they work as much as men, or they carry out the same activities. Thus, as they believe that they are just helping, they are more exposed to the hazards of activities which promote handling and/or exposure to chemicals without proper protection ${ }^{11}$.

Therefore, the main attention must be driven to pregnant women, who entail the population at risk. Research in this area point to pregnancy complications and abnormalities, often unknown by the women. That issue unveils emerging health care concern, evidencing the high risk that a vulnerable population, such as the pregnant women, is exposed to ${ }^{9}$.

According to what was mentioned above, and the absence of studies with that population, this research objectifies to verify and compare female farmworkers and female tobacco farmworkers' behavior regarding the pesticide use after discovering their pregnancy, and its auditory effects on infants.

\section{METHODS}

It is an analytical, observational cross-sectional study, approved by the Ethics Board on Research at Midwestern State University (Universidade Estadual do Centro-Oeste) under protocol number 1639354.

The current study was held at a Teaching Clinic located in the municipality of Irati (Paraná State, Brazil), and the sample comprised mothers who take their children for the hearing screening between June, 2016 and July, 2017. The "Infant hearing screening in Irati and surroundings" was implemented in 2007 (Projeto TOIR, in Portuguese), and screens the newborn in Irati and other eight neighboring municipalities.

The sample was defined by convenience. Fifty-nine (59) farming mothers participated in the study, and was checked the result of the hearing screening for 59 
infants, those women's children, residents in the cities registered in the Projeto TOIR.

The women were divided in two groups: Group F, entailing 25 tobacco farming mothers, and Group A (control), entailing 34 farming mothers of other crops (not tobacco crop).

As for the inclusion criteria, female participants should work in the fields, tobacco farming, or other crops, ages ranging between 18 and 45 years. Cases of exclusion occurred when length of time at farm work was inferior to 6 months, and/or the use of ototoxic medication was superior to fifteen days during pregnancy.

The study was carried out in two steps: the first was the application of a questionnaire with female farmworkers in order to verify their pesticide exposure.

The questionnaire entailed three objective questions, based on the KAP protocol "Knowledge, Attitudes and Practices", translated and transculturally adapted to the Portuguese language ${ }^{9}$, as follows: "To stop working after the pregnancy diagnosis; since getting pregnant, to make use of pesticides around the houses in order to exterminate the plagues; to apply some kind of pesticides". In addition, other four questions on the tobacco crop in the studied region: "To make use of pesticides; to do the laundry of clothes worn during the chemicals application; length of time at farm work; crop currently produced." The participants were asked individually/ orally and their answers were recorded in printing material.
In the second step, infants' hearing screening was held, considering the Pass/Fail result and the data collection of the Risk Indicators for Hearing Loss $(\mathrm{RIHL})$, which were then compared between the infants of tobacco farming mothers and non-tobacco farming mothers.

The procedures of the hearing screening included meatoscopy, followed by anamnesis with their mothers, in order to verify the presence, or not, of some RIHL, based on those considered by the Multiprofessional Committee on Hearing Health - COMUSA, in Portuguese ${ }^{10}$.

In order to capture the Transient Evoked Otoacoustic Emissions (TEOAE), the Interacoustics ${ }^{\circledR}$ equipment was used. The method aims to detect cochlear hearing loss. The PASS criterium used in the Projeto TOIR is the signal-noise ratio $\geq 6 \mathrm{~dB}$ in 3 or more frequency bands. Babies evidencing any RIHL or failing the screening are referred to follow-up, according to the Guidelines of the Hearing Screening ${ }^{11}$ or otorhinolaryngological test, respectively.

The results were organized and double-digitized in Microsoft Excel ${ }^{\circledR}$ spreadsheets. Chi-square test was used for the association between two variables, significance level of $5 \%(p<0,05)$.

\section{RESULTS}

From the 59 female participants in the study, 25 (42.37\%) work exclusively in the tobacco fields (Group F), while $34(57.62 \%)$ are farmworkers of other crops (Group A).

Table 1. Association of exposure to pesticides between the groups

\begin{tabular}{|c|c|c|c|c|c|c|}
\hline \multirow[b]{2}{*}{ Questions } & \multirow{2}{*}{$\begin{array}{c}\text { Group } \\
\text { (F) } n=25 \\
\text { (A) } n=34\end{array}$} & \multicolumn{2}{|c|}{ Yes } & \multicolumn{2}{|c|}{ No } & \multirow[b]{2}{*}{ (p) } \\
\hline & & $\mathrm{n}$ & $\%$ & $\mathbf{n}$ & $\%$ & \\
\hline \multirow{2}{*}{ Stopped working after pregnancy discovery } & $\mathrm{F}$ & 17 & 28.8 & 8 & 13.6 & \multirow{2}{*}{0.643} \\
\hline & $A$ & 25 & 42.4 & 9 & 15.3 & \\
\hline \multirow{2}{*}{ Use of pesticides around the residence } & $\mathrm{F}$ & 8 & 13.6 & 17 & 28.8 & \multirow{2}{*}{0.977} \\
\hline & A & 11 & 18.6 & 23 & 39.0 & \\
\hline \multirow{2}{*}{ Applied pesticides } & $\mathrm{F}$ & 5 & 8.5 & 20 & 33.9 & \multirow{2}{*}{0.098} \\
\hline & A & 2 & 3.4 & 32 & 54.2 & \\
\hline \multirow{2}{*}{ Use of pesticides } & $\mathrm{F}$ & 23 & 39.0 & 2 & 3.4 & \multirow{2}{*}{$0.043^{*}$} \\
\hline & $A$ & 24 & 40.7 & 10 & 16.9 & \\
\hline
\end{tabular}

Chi-square Test ${ }^{*} p=<0.05 ; F=$ Female Tobacco Farmworkers; $A=$ Female Farmworkers 
There was not statistically significant difference in the correlation between stop working after the pregnancy diagnosis and use of pesticides around the house to eliminate plagues. There was statistically significant difference for the factor use of pesticides in the field $(p=0.043)$, and it was evidenced probable statistical difference for the issue of pesticide application by the women $(p=0.098)$.

Table 2. Association between the results in the Pass/Fail test of infants' hearing screening and exposure to pesticides of group F

\begin{tabular}{|c|c|c|c|c|c|c|}
\hline \multirow[b]{2}{*}{ Questions } & \multirow{2}{*}{$\begin{array}{c}\text { Pass/Fail } \\
\text { (P) } n=54 \\
\text { (F) } n=5\end{array}$} & \multicolumn{2}{|c|}{ Yes } & \multicolumn{2}{|c|}{ No } & \multirow[b]{2}{*}{ (p) } \\
\hline & & $\mathrm{n}$ & $\%$ & $\mathrm{n}$ & $\%$ & \\
\hline \multirow{2}{*}{ Stopped working after pregnancy diagnosis } & $P$ & 39 & 66.1 & 15 & 25.4 & \multirow{2}{*}{0.564} \\
\hline & $\mathrm{F}$ & 3 & 5.1 & 2 & 3.4 & \\
\hline \multirow{2}{*}{ Use of pesticides around the residence } & $P$ & 16 & 27.1 & 38 & 64.4 & \multirow{2}{*}{0.164} \\
\hline & $\mathrm{F}$ & 3 & 5.1 & 2 & 3.4 & \\
\hline \multirow{2}{*}{ Applied pesticides } & $P$ & 6 & 10.2 & 48 & 81.4 & \multirow{2}{*}{0.557} \\
\hline & $\mathrm{F}$ & 1 & 1.7 & 4 & 6.8 & \\
\hline \multirow{2}{*}{ Use of pesticides } & $P$ & 44 & 74.6 & 10 & 16.9 & \multirow{2}{*}{0.254} \\
\hline & $F$ & 3 & 5.1 & 2 & 2.4 & \\
\hline
\end{tabular}

Chi-square Test ${ }^{*} \mathrm{p}=<0.05 ; \mathrm{P}=$ Pass; $\mathrm{F}=$ Fail

$5.1 \%$ of the infants, whose farming mothers make use of pesticides in the fields, failed the hearing screening. The same percentage was evidenced in the infants of mothers who use pesticides around their residence to eliminate plagues. There was not statistically significant difference between the infants' Pass/Fail result variables and exposure to pesticides (Table 2).

Table 3. Association between the infants' pass/fail results and laundry of clothes worn during pesticide application

\begin{tabular}{|c|c|c|c|c|c|c|}
\hline \multirow[b]{2}{*}{ Questions } & \multirow{2}{*}{$\begin{array}{l}\text { Pass/Fail } \\
\text { (P) } n=44 \\
\text { (F) } n=4\end{array}$} & \multicolumn{2}{|c|}{ Yes } & \multicolumn{2}{|c|}{ No } & \multirow[b]{2}{*}{ (p) } \\
\hline & & $\mathrm{n}$ & $\%$ & $\mathbf{n}$ & $\%$ & \\
\hline Laundry of clothes worn during pesticide & $P$ & 40 & 83.3 & 4 & 8.3 & 0.018 * \\
\hline application & $\mathrm{F}$ & 2 & 4.2 & 2 & 4.2 & $0.018^{\star}$ \\
\hline
\end{tabular}

Chi-square Test ${ }^{*} p=<0.05 ; P=$ Pass; $F=$ Fail

In Table 3, a statistically significant difference between infants' Pass/Fail result variables and laundry of clothes worn during pesticide application $(p=0.018)$ was evidenced. Mothers who did not report the laundry of clothes worn during pesticide application, were not included in this association. 
Table 4. Association between infants' pass/fail results and length of time at farm work

\begin{tabular}{|c|c|c|c|c|c|c|c|c|}
\hline \multirow{2}{*}{$\begin{array}{l}\text { Pass/Fail } \\
\text { (P) } n=54 \\
\text { (F) } n=5\end{array}$} & & \multicolumn{2}{|c|}{1 to 10 years } & \multicolumn{2}{|c|}{11 to 20 years } & \multicolumn{2}{|c|}{21 to 30 years } & \multirow[b]{2}{*}{ (p) } \\
\hline & & $\mathbf{n}$ & $\%$ & $\mathbf{n}$ & $\%$ & n & $\%$ & \\
\hline Tempo de Trabalho & $P$ & 31 & 52.5 & 15 & 25.4 & 8 & 13.6 & 0.910 \\
\hline na lavoura & $\mathrm{F}$ & 3 & 5.1 & 1 & 1.7 & 1 & 1.7 & 0.510 \\
\hline
\end{tabular}

Teste Qui-Quadrado * $\mathrm{p}=<0,05 ; \mathrm{P}=$ Pass; $\mathrm{F}=$ Fail

There was not association between the variables of the Pass/Fail results and length of time at farm work.
In Table 5, there was a statistically significant different between the variables for infants' Pass/Fail results and Risk Indicators for Hearing Loss $(p=0.046)$.

Table 5. Association between infants' pass/fail and risk indicators for hearing loss

\begin{tabular}{cccccc}
\hline Pass/Fail & \multicolumn{3}{c}{ Com IRDA } & \multicolumn{3}{c}{ Sem IRDA } & \multirow{2}{*}{ (p) } \\
\cline { 2 - 5 }$(\mathbf{P}) \mathbf{n}=\mathbf{5 4}$ & $\mathbf{n}$ & $\%$ & $\mathbf{n}$ & $\%$ & \\
$(\mathbf{F}) \mathbf{n}=\mathbf{5}$ & 11 & 18.6 & 43 & 72.9 & \multirow{2}{*}{$0.046^{\star}$} \\
\hline Passed & 3 & 5.1 & 2 & 3.4 & \\
Failed & &
\end{tabular}

Chi-square Test ${ }^{\star} \mathrm{p}=<0.05 ; \quad \mathrm{RIHL}=$ Risk Indicators for Hearing Loss; $\mathrm{P}=$ Pass; $F=$ Fail

Table 6. Association of infants' pass/fail results and risk indicators for hearing loss between the groups of mothers

\begin{tabular}{cccccc}
\hline Grupos & \multicolumn{5}{c}{ Infants } \\
\cline { 2 - 5 }$(\mathbf{F}) \mathbf{n}=\mathbf{2 5}$ & \multicolumn{2}{c}{ Tobacco Farming Mothers } & \multicolumn{2}{c}{ Farming Mothers } & \multirow{2}{*}{ (p) } \\
\cline { 2 - 5 }$(\mathbf{A}) \mathbf{n}=\mathbf{3 4}$ & $\mathbf{( n )}$ & $\mathbf{( \% )}$ & $\mathbf{( n )}$ & $\mathbf{( \% )}$ & $0.5644^{\prime}$ \\
\hline Without RIHL' & 20 & 33.9 & 25 & 42.4 & \\
With RIHL' & 5 & 8.5 & 9 & 15.3 & $0.911^{\prime \prime}$ \\
Passed"' & 23 & 39.0 & 31 & 52.5 & \\
Failed" & 2 & 3.4 & 3 & 5.1 & \\
\hline
\end{tabular}

Chi-squareTest ${ }^{*} p=<0.05$

$\mathrm{RIHL}=$ Risk Indicators for Hearing Loss; $\mathrm{F}=$ Female Tobacco Farmworkers; $\mathrm{A}=$ Female Farmworkers

(') = Association of the results of Risk Indicators for Hearing Loss (RIHL) between the groups of mothers.

(') = Association of the results of the Pass/Fail between the groups of mothers.

In Table 6, it is possible to observe that infants of farming mothers passed the TEOAE with greater rate of RIHL, as well as they failed the TEOAE with greater rate, without evidencing any RIHL. There was not statistically significant difference between the correlation of the Pass/Fail results and the Risk Indicators for Hearing Loss in infants of the groups (female tobacco farmworkers and other female farmworkers). 


\section{DISCUSSION}

From the results obtained in this study, statistical significance in the correlation of pesticide exposure between the groups of Female Tobacco Farmworkers and other Female Farmworkers was not observed. However, in both groups, women did not stop working in the fields after the pregnancy diagnosis. That fact points out a public health problem: high exposure of those women to pesticides, farm products and, in the case of the tobacco farmworkers, to nicotine and other tobacco-derived compounds during pregnancy. That can be justified by the fact that women have high participation in the workforce, as well as in their family income, thus they cannot afford to stop working during pregnancy. Factors such as health status, access to health care services, social vulnerability and income were not investigated in this study, however, they seem to be determinant and risk-conditioning to reproductive health ${ }^{12}$.

8.861 Bill from March 25th, 1994, warrants maternity leave to urban, rural and domestic female workers, as well as a maternity-salary to the female small-scale farmworkers (as specially entitled to it) and other female workers. However, due to the harmful hazards that those farmworkers are exposed to, that payment is unfeasible and insufficient, as it is provided for only 120 days, and they are entitled to it at least 28 days before delivery or on the delivery date ${ }^{13}$.

Tobacco farming poses workers with several hazards during their activities, and the associated effects may harm their health, in this case, female farmworkers, as well as resulting in deleterious health effects on their children. In India, study carried out with 685 female tobacco farmworkers and 655 female farmworkers from other crops, identified higher prevalence of hypertension and preterm deliveries in tobacco farmworkers, comparing them to the control group. Authors assume that even though those results are not definitive, due to the sample number, different dosages of nicotine, inhaled along the several stages of the tobacco crop and mainly, the inexistence of other comparative studies ${ }^{14}$.

Regarding the use of pesticides in the fields, it was evidenced statistically significant difference, showing that tobacco crop is straight correlated with the use of pesticides, which implies that the degree of contamination is greater if compared to other crops. It can still be observed, keeping data in mind, the probable statistically significant trend of pesticides being applied by women, showing that female tobacco farmworkers perform this task more often than other female farmworkers from other crops. Study held with information of live births from the Live Births Information System, Brazilian Ministry of Health, verified the greatest association between the use of pesticides and congenital malformations of the circulatory system in higher pesticide-exposed municipalities from Paraná State, Brazil, between 1994 and 2014, as follows: undescended testicles, followed by congenital malformations of the circulatory system and, finally, cleft lip and cleft palate ${ }^{15}$.

Study held in Maringá, Paraná State, Brazil and surroundings, by means of analysis of records from a supporting association, verified the prevalence of cleft lip and palate in a sample of 421 individuals. The prevalence of cleft lip and palate was in $56.6 \%$ of male individuals, the most prevalent was incisive transforamen cleft $(44.55 \%)$, followed by post-foramen cleft $(27.38 \%)$, pre-foramen cleft $(23.90 \%)$ and rare clefts (4.18\%). When etiological factors were investigated, it was evidenced parental exposure, mainly maternal exposure to teratogen factors, such as drugs, alcohol, syphilis, seizure medication, lack of pre-natal follow-up and exposure to pesticides ${ }^{16}$.

Still regarding pesticide exposure, a populationbased study carried out in Mato Grosso State, Brazil, where eight municipalities were selected for presenting the highest human exposure to pesticides, found $100 \%$ greater occurrence of congenital malformations among children of mothers exposed to pesticides during the perinatal period than among other mothers ${ }^{17}$.

In the current study, no significant difference was observed between the TEOE Pass/Fail results and length of time at farm work. Such a result can be justified by the small number of the sample, and absence of clinical validation of the instrument (questionnaire) used. The consideration of such factors is suggested in further studies.

The association between the TEOE Pass/Fail results and laundry of clothes worn during the pesticide application evidenced statistically significant difference, pointing to an indirect way of pesticide and/or other chemicals exposure/contamination. The pesticides deposited in clothes and the contact with them in the water, during laundry, may be dermal-route contaminating. Studies show that it is common practice for wives to do the laundry of their husbands' pesticidecontaminated clothes, and therefore, greater occurrences of congenital malformations were reported among their infants ${ }^{18-20}$. 
There was association between the infants' results in the Pass/Fail and the Risk Indicators for Hearing Loss $(\mathrm{RIHL})$, where the highest rate $(5.1 \%)$ of infants who fail the TEOE evidenced RIHL, and they were farmworkers' infants. COMUSA points to the incidence of 1 to 3 for each 1,000 live births without reporting RIHL, while for the newborn cared at the Intensive Care Units (ICU), rate ranges from 1 to 4 for 1,000 newborn. The current study evidenced three cases, corresponding to $60 \%$ of the infant population who failed RIHL, unveiling that such a rate is higher than the rates established for the incidence of hearing loss among the live births, corresponding to $0.3 \%$ in a total of 1,000 live births. Those data warns the occurrence of high rate of infants who failed the TEOE, with the presence of the RIHL, thus they should be followed up due to the susceptibility to late development of hearing loss ${ }^{11}$.

The fact that farmworkers' infants passed with higher rate of RIHL differs from data reported in a study which objectified to investigate the probable maternal and fetal effects after inhaling Flumetralin, sort of growth inhibitor of axillary gems, used in tobacco fields. Maternal and fetal effects were observed in mice after 10 to 20-minute inhalation and euthanasia procedure. The fetal effects were visceral injuries in womb, kidneys, liver, skeletal abnormalities, hydrocephalus, and incomplete skull ossification. For a 20-minute exposure, it was also evidenced abnormalities in the occipital bone, thirteenth rib and internal bleeding. It was still verified the reduction in maternal weight gain, and in the intrauterine development of the fetus. Fetus's heart, liver, kidneys and testicles had weight reduction. Thus, it is evidenced the potential of this chemical to provoke teratogenic effects, causing structural and functional malformations, representing high threat to the reproductive health, thus, configuring RIHL, if considered its effects on human beings ${ }^{21}$.

However, in this study, there was no statistically significant association between the infants' Pass/Fail results and the Risk Indicators for Hearing Loss (HIRL) between the groups of tobacco farming mothers and other farming mothers.

Study which assessed the association between the medial olivocochlear function and genotoxic biomarkers among 25 students from the tobacco farming region did not evidence any abnormalities in the medial olivocochlear system through the suppression of emissions, but it evidenced higher rates of damage in the genotoxic biomarkers. The research comprised a group of 21 normal listeners from the tobacco farming region, and another with 25 students, normal listeners, who did not live in the rural area. By means of the method of detection by Suppression of Distortion Product Otoacoustic Emissions, the medial olivocochlear system was assessed, and as genotoxic biomarkers, comet assay was used, micronucleus test and fluorometric assay for DNA quantification. The group of students from the tobacco farming region did not show any disorders in the medial olivocochlear system, evidenced by the presence of emission suppression, but they presented higher damage rates in the genotoxic biomarkers. There was no association between the disorders in the medial olivocochlear system and suppression and genotoxicity ${ }^{22}$.

As suggested by COMUSA, the objective methodologies for registering cochlear hearing loss (Peripheral Hearing Nervous System - PHNS), and retro-cochlear disorders (Central Hearing Nervous System - CHNS) are the Evoked Otoacoustic Emissions (EOAE) and the Brainstem Auditory Evoked Potential (BAEP), respectively. There was not cochlear hearing loss in the former study (cochlear disorders). Similarly, in the current study, there was no statistically significant difference in the association held between the infants of tobacco farming mothers' and other farming mothers. Infants from tobacco farming mothers did not fail the EOAE in higher rate, maybe for the fact that retro-cochlear injuries could not be evidenced in this study by the applied method. It is highlighted the need of further investigations on retro-cochlear injuries, which cannot be detected by means of the EOAE. Therefore, as it was already proposed in a study with adults, hearing effects by chemical substances are better evidenced and cause greater damage to the CHNS, and can be investigated by means of methods which screen brainstem pathways ${ }^{23,24}$.

It is an issue to be carefully treated. In a cohort study carried out in a farming region in Jiangsu province, China, which investigated pre-natal and post-natal exposure to organophosphate pesticides and neurological child development, it was evidenced, in one of its results, that boys featured adverse associations to organophosphate exposure in the pre-natal and postnatal periods, with developmental delay. However, such associations were not reported in girls. Thus, pre-natal as well as post-natal exposure to organophosphate pesticides may adversely affect the neurological development of children living in farming areas ${ }^{25}$.

The limits pointed by toxicological studies, which enable to establish the immuno-toxic potential as well 
as endocrine disruption of substances are evident, therefore, raising the risk of exposure and outcomes in human beings. There is no precise information on the effects from several contamination sources and their synergism, such as food, water, air, among other available sources, thus affecting populations who are not directly involved in pesticide handling, for example. However, what we know is that low-level exposure to chemicals may already trigger catastrophic effects during the so-called critical phases of development, such as pregnancy, infancy or childhood ${ }^{20,26}$

\section{CONCLUSION}

The data presented in this study are not definitive, however, they unveil an outstanding problem, recurrent in several rural areas in Brazil, where tobacco is produced.

There was the association of pesticide exposure, occurred between the groups of female tobacco farmworkers and other female farmworkers, in the factor related to the use of pesticides, evidencing that tobacco crop is closely related to the use of pesticides. Among the results of infants' Pass/Fail test and laundry of clothes worn during the pesticide application, there was statistically different association, pointing to the indirect contamination/intoxication of those women by pesticides, which may influence their gestational term. The association between the infants' Pass/Fail results and the Risk Indicators for Hearing Loss (RIHL) between the groups (female tobacco farmworkers and other female farmworkers), did not evidence any statistically significant differences.

Effects of female tobacco farmworkers and other female farmworkers' exposure on their infants' hearing health were not evidenced, but the EOAE registering method did not detect retro-cochlear injuries. Further research studies on the theme are suggested.

\section{REFERENCES}

1. Carneiro FF, Rigotto RM, Augusto LG da S, Friedrich K, Búrico AC. Dossiê ABRASCO: um alerta sobre os impactos dos agrotóxicos na saúde. São Paulo: Expressão Popular, 2015.

2. Cargnin MCS, Echer IC, Silva DR. Fumicultura: uso de equipamento de proteção individual e intoxicação por agrotóxico. Rev Fund Care Online. [periódico na Internet]. 2017 [acesso em: 19 de set de 2017]; 9(2):[466-72]. Disponível em: http://seer. unirio.br/index.php/cuidadofundamental/article/ view/5444

3. Londres F. Agrotóxicos no Brasil: um guia para ação em defesa da vida. Rio de Janeiro: AS-PTA - Assessoria e Serviços a Projetos em Agricultura Alternativa. 2011.

4. Tabaco no sul do Brasil: tradição e renda. [acesso em: 19 de set de 2017]. Disponível em:http://sinditabaco.com.br/wpcontent/ uploads/2013/03/12620_2013_arquivo_pdf_ relatorio_tabaco_sul_brasil_2013.pdf

5. Secretaria de Estado da Agricultura e do Abastecimento. Fumo - Análise da Conjuntura Agropecuária. [acesso em: 21 de set de 2017]. Disponível em: http://www.agricultura. pr.gov.br/arquivos/File/deral/Prognosticos/ fumicultura_2013_14.pdf

6. Rodrigues AH, Stalder ST, Xavier CR. A saúde e seus significados para famílias fumicultoras da região de Irati (PR): contingências e contradições. Saúde em Debate [periódico na Internet]. 2016 [acesso em: 20 de set de 2017]; 40(111):[220-9]. Disponível em: $\quad$ http://www.scielo.br/scielo.php?script $=$ sci arttext\&pid $=$ S0103-11042016000400220\&lng $=p t \&$ tlng $=p t$

7. Riquinho DL, Hennington EA. Health, environment and working conditions in tobacco cultivation: a review of the literature. Cien Saude Colet. [periódico na Internet]. 2012 [acesso em: 19 de set de 2017];17(6):[1587-600]. Disponível em: http:// www.scielo.br/pdf/csc/v17n6/v17n6a22.pdf

8. Schlindwein V de LDC. Dor e sofrimento oculto: a desproteção social dos trabalhadores do fumo. Barbarói. [periódico na Internet] 2010 [acesso em: 21 de set de 2017];1(32):[82-97]. Disponível em: https://online.unisc.br/seer/index.php/barbaroi/ article/viewFile/1135/1085

9. Brumer A. Gênero e agricultura: a situação da mulher na agricultura do Rio Grande do Sul. Rev Estud Fem. [periódico na Internet] 2004 [acesso em: 25 de set de 2017];12(1):[205-27]. Disponível em: http://www.scielo.br/pdf/ref/v12n1/21699.pdf

10. Cassol K, Magni C. Tradução e adaptação transcultural para a língua portuguesa do protocolo KAP "Knowledges, Attitudes and Practices." In: Instituto Pantex de Pesquisa. V Convibra - Gestão, Educação e Promoção da Saúde: Melhores Artigos. Kindle. 2017.

11. Lewis DR, Nódrega SAM, Mendes BCA, Cruz OLM, Nódrega M de. Comitê multiprofissional em 
saúde auditiva: COMUSA. Braz J Otorhinolaryngol [periódico na Internet]. 2010 [acesso em: 02 de out de 2017];76(1):[121-8]. Disponível em: http://www. scielo.br/pdf/bjorl/v76n1/v76n1a20.pdf

12. Xavier RB, Jannotti CB, Silveira K. Risco reprodutivo e renda familiar: análise do perfil de gestantes. Cien Saude Colet. [periódico na Internet]. 2013 [acesso em: 02 de out de 2017]; 18(4):[1161-72]. Disponível em: http://www.scielo.br/scielo.php?pid=S141381232013000400029\&script $=$ sci_abstract

13. BRASIL. Lei no 8.861 , de 25 de março de 1994. Presidência da república casa civil subchefia para assuntos jurídicos. [acesso em: 02 de out de 2017] Disponível em: http://www.planalto.gov.br/ ccivil_03/leis/L8861.htm

14. Parikh JR, Gokani VN, Doctor PB, Kulkarni PK, Shah AR, Saiyed HN. Acute and chronic health effects due to green tobacco exposure in agricultural workers. Am J Ind Med. [periódico na Internet]. 2005 [acesso em: 04 de out de 2017];47(6):[494-9]. Disponível em: http://www.scopus.com/inward/ record.url?eid=2-s2.0-20444402295\&partnerlD $=40$ $\& m d 5=a 6896$ ba25ed4353ec2b0be27c502317e

15. Silva Dutra L, Ferreira AP. Associação entre malformações congênitas e a utilização de agrotóxicos em monoculturas no Paraná, Brasil. Saúde em Debate. [periódico na Internet]. 2017 [acesso em: 11 de out de 2017];41(2):[241-53]. Disponível em: http:// www.scielo.br/scielo.php?script $=\mathrm{sci}_{-}$ arttext\&pid $=$ S0103-11042017000600241\&lng $=$ pt\& tlng $=\mathrm{pt}$

16. Costa RR, Takesshita WM, Jacobucci Farah G. Levantamento epidemiológico de fissuras labiopalatais no município de Maringá e região. Rev Assoc Paul Cir Dent. [periódico na Internet]. 2013 [acesso em: 11 de out de 2017];67(1):[40-4]. Disponível em: http://revodonto.bvsalud.org/pdf/ apcd/v67n1/a07v67n1.pdf

17. Oliveira NP, Moi GP, Atanaka-Santos M, Mário A, Silva C. Malformações congênitas em municípios de grande utilização de agrotóxicos em Mato Grosso, Brasil. Ciênc. Saúde coletiva [periódico na Internet]. 2014 [acesso em: 11 de out de 2017];19(10):[4123-30]. Disponível em: $\quad$ http://www.scielo.br/scielo.php?script $=$ sci_ arttext\&pid $=$ S1413-81232014001004123\&lng $=$ en

18. Benítez-Leite S, Macchi M, Acosta M. Malformaciones congénitas asociadas a agrotóxicos. Pediatría (Asunción) [periódico na Internet]. 2007 [acesso em: 12 de out de 2017];34(2):[111-21]. Disponível em: http:// scielo.iics.una.py/scielo.php?script $=$ sci_arttext\& pid $=$ S1683-98032007000200002

19. Engel LS, O'Meara ES, Schwartz SM. Maternal occupation in agriculture and risk of limb defects in Washington State, 1980-1993. Scand J Work Environ Heal. [periódico na Internet]. 2000 [acesso em: 12 de out de 2017];26(3):[193-8]. Disponível em: file://C:/Users/Usuario/ Downloads/a_26_3_193\%20(2).pdf

20. Amaral EI, Rosa ACS, Sarcinelli PDN. Avaliação da exposição ambiental ao glifosato na área agrícola da Serrinha do Mendanha. Pestic Rev Ecotoxicologia e Meio Ambient [periódico na Internet]. 2013 [acesso em: 02 de nov de 2017];23(1):[67-74]. Disponível em: http://revistas. ufpr.br/pesticidas/article/view/34998

21. Boneventi $P$, Baroneza JE, Moreira $C Q$, Santos DCDM dos, Salles MJS. Maternal and fetal effects after inhalation of the herbicide flumetralin. Acta Sci Biol Sci. [periódico na Internet]. 2015 [acesso em: 02 de nov de 2017];37(4):[477-81]. Disponível em: $\quad$ http://periodicos.uem.br/ojs/index.php/ ActaSciBiolSci/article/view/26769/pdf_88

22. Kunst LR, Garcia MV, Machado AK, Barbisan F, Silveira AF da. Medial olivocochlear system and genotoxicity in students of the tobacco-producing region. Rev. CEFAC. [periódico na Internet]. 2014 [acesso em: 02 de nov de 2017]; 16(6):[1751-62]. Disponível em: http://www.scielo.br/pdf/rcefac/ v16n6/en_1982-0216-rcefac-16-06-01751.pdf

23. Cavallieri GV, Alcarás PA de S, Corazza MCA, Corazza LA. The hearing of smokers: a review. Rev. CEFAC. [periódico na Internet]. 2017 [acesso em: 02 de nov de 2017];19(3):[406-16]. Disponível em: $\quad$ http://www.scielo.br/scielo.php?script $=$ sci arttext\&pid $=$ S1516-18462017000300406\&lng $=e n \&$ $\mathrm{nrm}=$ iso\&tlng $=$ en

24. Mont'Alverne LR, Corona AP, Rêgo MAV. Perda auditiva associada à exposição ocupacional a solventes orgânicos: uma revisão sistemática. Rev Bras Saúde Ocup. [periódico na Internet]. 2016 [acesso em: 02 de nov de 2017];41(10):[126]. Disponível em: http://www.scielo.br/ scielo.php?script $=$ sci_arttext $\&$ pid $=$ S0303$76572016000100402 \&$ lang $=\mathrm{pt} \% 5 \mathrm{Cnh}$

25. Liu $P$, Wu C, Chang $X$, Qi X, Zheng $M$, Zhou Z. Prenatal and postnatal exposure to organophosphate pesticides and child 
neurodevelopment in an agricultural area of Jiangsu province, China: a cohort study. Environ Health Perspect. [periódico na Internet]. 2016 [acesso em: 02 de nov de 2017];124(10):[163743]. Disponível em: http://dx.doi.org/10.1016/ S0140-6736(15)00664-9

26. Friedrich K. Desafios para a avaliação toxicológica de agrotóxicos no Brasil: desregulação endócrina e imunotoxicidade. Vig San em Deb. [periódico na Internet]. 2013 [acesso em: 02 de nov de 2017];1(2):[2-15]. Disponível em: http://www. visaemdebate.incqs.fiocruz.br/index.php/ visaemdebate/article/view/30/34 